\title{
Impact of Industrial Policy on the Growth of Micro, Small And Medium Enterprises in Uttar Pradesh
}

\author{
${ }^{1}$ Dr Geetika T. Kapoor, ${ }^{2}$ Ravi Kant Mani Tripathi \\ ${ }^{1}$ Assistant Professor, ${ }^{2}$ Research Scholar, Department of Commerce, University of Lucknow, \\ Lucknow, India. 1 geetika.t.kapoor@gmail.com, ${ }^{2}$ maniravitripathigkp@gmail.com
}

ABSTRACT - The Micro, Small and Medium enterprises sector is a very dynamic and upcoming sector of the Indian economy. It has emerged as a great contributor to the economic development of the country by providing huge employment opportunities. It encourages self -dependency by stimulating entrepreneurship thereby ensuring social development of the country. As the capital cost is low it has proved to be India's boon after Agriculture in the past few decades. Currently there are approximately 633.8 lakh units spread throughout the country, contributing around $28.90 \%$ to the GDP and $49 \%$ to total exports of the country.

The target set by MSME ministry is a contribution 50\% to the GDP by 2025 as India forges ahead to achieve a $\$ 5$ trillion economy. Uttar Pradesh has approximately 89.99 lakh MSME's which is around 14.20\% share of the total no of MSME's in India as per NSS $73^{\text {rd }}$ Round (15-16). In products like handicrafts, engineering goods, carpets, readymade garments, leather products of the MSME sector, U.P. is a lead exporter. The Government of U.P. recently launched the scheme of One District One Product (ODOP) among many other schemes to foster and encourage the setting up of more MSME's. Uttar Pradesh (UP) has the highest number of MSME units in the country followed by West Bengal and Tamil-Nadu.

With the help of this paper the growth in number of MSME units and MSME employment generation in Uttar Pradesh is studied. Provision in UP industrial policies for years 2004, 2012 and 2017 regarding MSME's units has also been examined.

KEYWORDS:_ MSME INDUSTRY IN UTTAR PRADESH, UP INDUSTRIAL POLICY, POLICY FOR MSMES IN UP, GOVERNMENT SCHEMES.

\section{INTRODUCTION}

Micro Small and Medium enterprises play a very important role in the growth and development of the country. MSME sector employs 1076.19 lakh people in India which is $97 \%$ of the total workforce. The MSME's are useful in providing livelihood to many households as well as improving the standard of living of such households. MSME contribute to approximately $28.90 \%$ to India's GDP and are responsible for $49 \%$ of its total exports. More than half of the total MSME units are located in the rural areas of the state like UP, Maharashtra, Tamil Nadu, West Bengal, Andhra Pradesh and Karnataka. This leads to a balanced distribution of national income, alleviates poverty and provides inclusive economic growth.

The definition of MSME is as follows:

Micro, Small and Medium enterprises are defined in terms of investment in the plant machinery and equipment as per the MSME ACT 2006.

\begin{tabular}{|l|l|l|}
\hline Classification & $\begin{array}{l}\text { Investment Limit for } \\
\text { Manufacturing } \\
\text { Enterprises }\end{array}$ & $\begin{array}{l}\text { Investment Limit for } \\
\text { Service Enterprises }\end{array}$ \\
\hline Micro & Up to 25 Lakh & Up to Rs.10 lakh \\
\hline Small & $\begin{array}{l}\text { Above 25 Lakh to 5 } \\
\text { Crore }\end{array}$ & $\begin{array}{l}\text { Above 10 Lakh to Rs. } \\
\text { 2 Crore }\end{array}$ \\
\hline Medium & $\begin{array}{l}\text { Above 5 Crore to 10 } \\
\text { Crore }\end{array}$ & $\begin{array}{l}\text { Above 2 Crore to 10 } \\
\text { Crore. }\end{array}$ \\
\hline
\end{tabular}

Source:-MSME Act 2006.

The total number of MSME's in the country is about;

630.5 lakh micro industries,

3.3 lakh small, and

5,000 medium enterprises. 
Figure : Broad Classification of the MSMEs in India

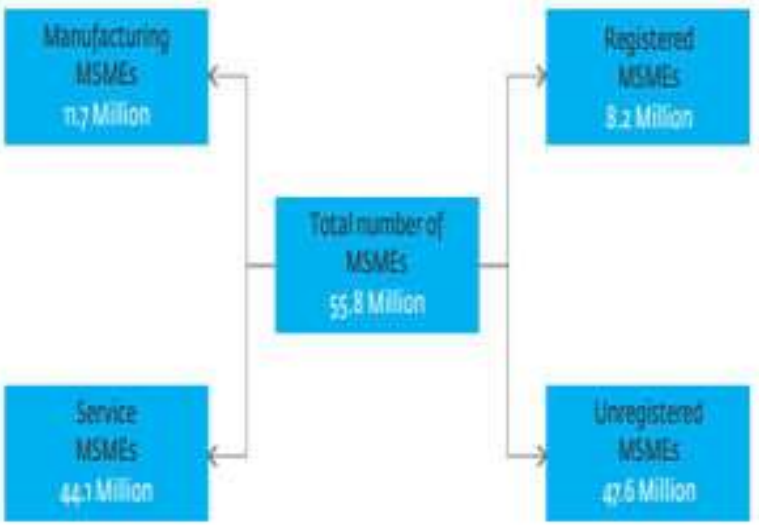

Give valsend ket

\section{REVIEW OF LITERATURE}

\section{KHANKA SS 1990}

He took a sample of 50 entrepreneurs from the western division of Uttar Pradesh which is a notified backward region and studied the small-scale businesses there. He found that the attributes of entrepreneurs could be seen in such small-scale enterprises. He also studied their performance and problems encountered by them right from entry into entrepreneurship to financing and marketing.

\section{VUASULU 2000}

Vuasulu deduced that for industrial progress of India, cottage and small-scale industries were indispensable. In the manufacturing sector of India their contribution was nearly $50 \%$ in gross value output terms. Further-more these industries generate large scale employment at relatively smaller costs, thus ensuring equal distribution of the national income. This will also result in decentralization of the industries and improve the standard of living in the society.

\section{RAJENDHIRAN (2005)}

In the paper "Role of Small Industries Development Bank of India in the Development of Small Scale Sector", the researcher has emphasized the role of SIDBI in providing all round help to the small scale industries right from setting up to technological, modernization, improving quality as well as enhancing exports of the units. SIDBI is further giving assistance in the form of loans without collateral to such units.

\section{PRASAD (2006)}

Has said in his article "Micro, Small, and Medium Enterprises Financing in India-Issues and Concerns", that an enterprise which is credit worthy will be able to draw more finance from financial institutions. The smallscale enterprises with low capital are not in a position to meet the conditions laid down by Banks regarding viability of the unit, collateral and repayment schedules.

\section{RAJESHKR.SINGH ET AL. (2007)}

In the paper "Comparative study on strategies of Indian Small, Medium and Large Scale Organizations" researchers have concluded that the main obstacle in the growth of Small and Medium scale entrepreneur was their reluctance to borrow from external agencies which resulted in outdated technology in their units.

\section{SANJEEV MANTRI (SEP 2008)}

Has suggested in his paper "ICICI Banks to Expects SME Advances Business to Grow by 20 Per Cent", points out that the ICICI banks should see the potential of credit expansion in the small and medium enterprises sector. In order to reach the target of $25 \%$ lending to this sector they should develop personal contacts with owners of such enterprises.

\section{MALLA (2009)}

In his study on "Financing of MSMEs- Issues and Concerns", the MSME entrepreneurs while borrowing from financial institutions said the main problems which arose were that of collateral requirements, high interest rates, documentation, limited outreach and rigid approach by Banks.

\section{HASEEB DRABU (2010)}

In the paper "Banks Need to Change Lending Model to Promote SMEs", he has suggested that Public Sector banks need to change their lending Model to SME's in order to improve the quality of lending. This they can do by proper project appraisal and monitoring of the project once loan is disbursed.

\section{KANISHKA GUPTA (2011)}

In her Paper "MSMEs Cash-Strapped", concluded that the MSMEs were unable to raise long term loans at competitive rates especially in the ever increasing globalization of the economy.

\section{RAJESH RAJ, S N AND MIHIR KM 2012}

In their study which covered SME's from various States it was observed that growth and productivity, and performance of small manufacturing enterprises was slower in the post reform period.

\section{MINISTRY OF MICRO SMALL AND MEDIUM ENTERPRISES 2013}

Published by the inter-ministerial committee reporting on slow-down in the overall growth of MSME's in the recent years especially after 2009. It said that from starting a business enterprise to running it smoothly many problems were encountered. In order to accelerate the growth of MSME's it was suggested that certain changes in labour legislations were required as well as a support system to these enterprises was to be provided. 


\section{ABDUL NASER V 2013}

In his study, the contribution of the MSMEs to the inclusive growth of the Indian economy was evaluated. The study shows that inclusive growth is registered as more than 50\% of the total MSMEs are located in rural areas promoting balanced regional development. These enterprises generate employment and increase exports from the country, thus heavily contributing to increase in industrial production and GDP of the country.

\section{SAINI P 2014}

Discussed the factors responsible for the slow growth of MSME's in her study. The main reasons as per Saini were difficulty in arranging for capital, licenses required and infrastructure problems which were inhibiting the progress of MSME's.

\section{RESEARCH METHODOLOGY}

Data used in the study is secondary in nature and collected from the annual reports published by the Ministry of Micro, Small and Medium Enterprises, Government of India. The number of MSME units additionally registered from 200708 to $2015-16$ and the current number of MSME's have been used for analyzing the growth of MSME's in U.P. Information about the increase in total number of employees engaged in the MSME sector is taken from U.P. Government Report, Department of MSME and Exports. With the help of tables and graphs the growth in the number of MSME's as well as employment generated through them is explained systematically.

\section{MICRO SMALL AND MEDIUM ENTERPRISES IN U.P.}

MSME sector forms the backbone of economic progress and development of any State because of its industrial productivity, employment generation and contribution in exports. The MSME sector account for almost $60 \%$ of the total industrial output in U.P. The State has over 88.99 Lakh MSME units.

\section{Policy and Program for growth of MSME Sector:}

The Industrial and Service Sector Investment Policy $\underline{2004}$

Emphasis was laid on the balanced development and harmonious growth of Tiny, Small and Heavy Sector. There was a provision for creation of facilities for traditional industries which are the backbone of the State economy in terms of better quality, marketing, packaging design and technology.

\section{Uttar Pradesh Infrastructure and Industrial Investment} Policy 2012

The industrial policy 2012 announced an objective of attaining the target of $11.2 \%$ industrial growth in UP.

The policy envisions establishing Uttar Pradesh as the most preferred destination for investment by accelerating industrial development, creation of a conducive business environment and development of high-end infrastructure facilities in order to create new employment opportunities. It offered key Fiscal incentives like Stamp duty concessions, exemption in entry tax and other taxes and exemption from Mandi fee.

\section{Industrial Investment and Employment Promotion Policy of Uttar Pradesh 2017}

Ensures all round industrial growth by improving flow of capital and credit to MSME's, capacity building, improving quality and standards, bringing in common facility centers, better marketing techniques and good governance practices.

\section{State Government ; MSME Policy and Schemes 2017}

The following programs are run by the State Government for improving the MSME sector in India

a. Employment Schemes like CM and Self Employment Scheme, ODOP,

PM Employment Program and Vishvakarma Labour schemes.

b. Training Programs for Scheduled castes, Scheduled Tribes and other backward castes

c. Pension Schemes like CM Pension scheme and Handicraft workers scheme

d. Other Schemes like Micro and Small Cluster Development Program, UP Technical Assistance Scheme, GEM Portal.

\section{Under this policy MSME sector was given a major} emphasis

1. Constitution of special cell in Directorate of Industry to undertake various studies for improving over-all environment for MSME growth.

2. Appointment of officer in-charge in directorate of industries for effective implementation of GOI scheme for MSME.

3. Rehabilitation policy for economically viable but sick units and new exit policy for unviable closed units.

\section{Registration of New MSMEs:}

For the development of MSME Sector in an economy, the data on opening of new MSMEs is crucial as it shows that the environment for opening and growth of such units is conducive. At the macroeconomic level, it also shows that the Entrepreneurs trust the policies of the Government and are highly motivated. Before the MSMED Act, 2006, the system of registration by small scale industrial units was to file $\mathrm{n}$ register with the DICs. But now as per the provisions of the MSMED Act, 2006, the entrepreneur concerned has to only file Entrepreneurs Memorandum (Part-II) /[EM-II] . From the year 2007 till 2017 about 21,96,902 EM-II filings were made.

\section{ANALYSIS OF DATA}

In this analysis data for growth of MSME units from 200708 to 2015-16 in U.P. has been undertaken. The data of employment generation through MSME units in Uttar 
Pradesh has also been analysed. The study is based on secondary data presented by annual reports of the concerned department of Uttar Pradesh Government and Government of India.

GROWTH OF MICRO SMALL AND MEDIUM ENTERPRISIS UNITS IN UTTAR PRADESH (EM-II Filled)

\begin{tabular}{|l|l|l|l|}
\hline Year & $\begin{array}{l}\text { Number of Additional } \\
\text { MSME units } \\
\text { registered in Uttar } \\
\text { Pradesh }\end{array}$ & $\begin{array}{l}\text { Increase in } \\
\text { number of } \\
\text { MSMEs in UP } \\
\text { from 2007-08 }\end{array}$ & Growth \\
\hline $2007-08$ & 30443 & & - \\
\hline $2008-09$ & 31629 & 1186 & 3.90 \\
\hline $2009-10$ & 33479 & 3036 & 9.97 \\
\hline $2010-11$ & 33027 & 2584 & 8.49 \\
\hline $2011-12$ & 32304 & 1861 & 6.11 \\
\hline $2012-13$ & 30933 & 490 & 1.61 \\
\hline $2013-14$ & 45342 & 14899 & 48.94 \\
\hline $2014-15$ & 52203 & 21760 & 71.50 \\
\hline $2015-16$ & $23402($ till September & & - \\
\hline
\end{tabular}

TABLE: 1 Source: MSME Report, Government of India 2015-16

\section{Growth \%}
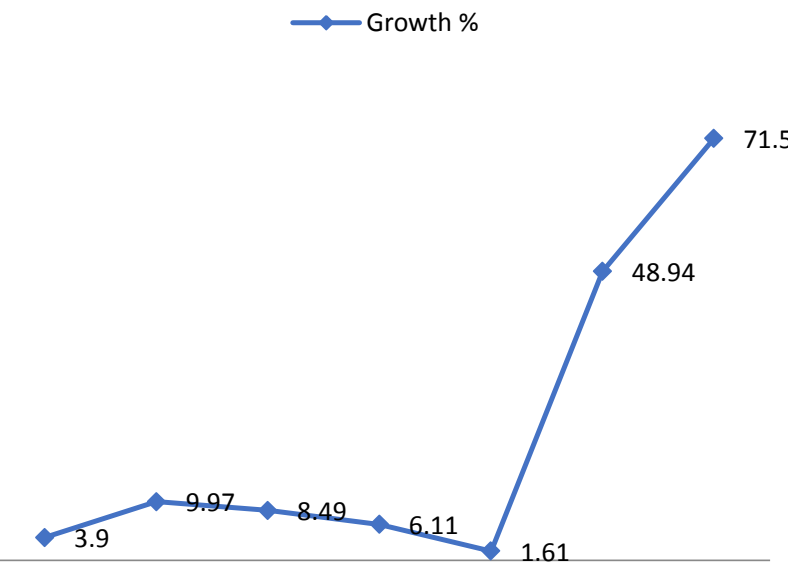

2008-09 2009-10 2010-11 2011-12 2012-13 2013-14 2014-15

As is clear from the above Table: 1 that there is a continuous rise in the number of MSME's with growth percentage reaching 71\% from 2007-08 till 2014-15. In a span of seven years the growth the number of EM-II units rose from 30443 units to 52203 units which are in addition to existing units.

As per the MSME Report 2018-19, the NSS (National Sample Survey) $73^{\text {rd }}$ round in 2015-16 Uttar Pradesh has the highest number of MSME's in India which is around 89.99 lakhs units.

While seeing growth pattern of MSME units in U.P, it can clearly be said that the efforts of the UP Government through its various policies, schemes and incentives have borne fruit and there is a healthy growth in the number of units of MSME's. It can also be deduced that with the growth in number of units, the employment figures have also been rising steadily throughout the last decade and especially in the last five years which shows that MSME is a promising sector for generating employment in the populous State of Uttar Pradesh.

\section{NUMBER OF EMPLOYEES ENGAGED IN SMALL- SCALE SECTOR}

\begin{tabular}{|l|l|l|l|l|}
\hline Year & Target & $\begin{array}{l}\text { Establishment } \\
\text { of MSMEs }\end{array}$ & $\begin{array}{l}\text { Capital } \\
\text { Employed } \\
\text { (In Crore) }\end{array}$ & $\begin{array}{l}\text { Employment } \\
\text { generation }\end{array}$ \\
\hline $2004-05$ & 30000 & 30402 & 284.34 & 121102 \\
\hline $2005-06$ & 30000 & 30282 & 262.79 & 125611 \\
\hline $2006-07$ & 30000 & 28487 & 507.59 & 120876 \\
\hline $2007-08$ & 33000 & 31734 & 1270.83 & 148985 \\
\hline $2008-09$ & 33000 & 33302 & 2046.80 & 171141 \\
\hline $2009-10$ & 33000 & 34063 & 3474.12 & 175504 \\
\hline $2010-11$ & 33000 & 34178 & 3188.43 & 175120 \\
\hline $2011-12$ & 33000 & 33532 & 3452.93 & 186755 \\
\hline
\end{tabular}

TABLE: 2 Source: Annual report 2011-12, Department of MSME and export promotion, Government of Uttar Pradesh.

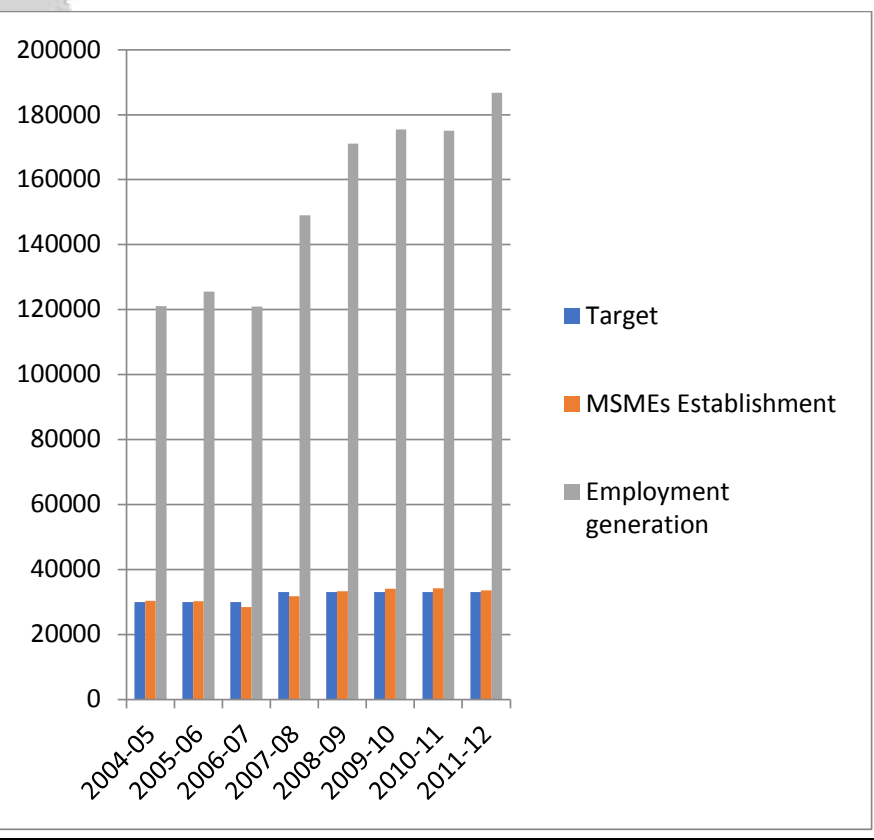

Source: Annual report 2011-12, Department of MSME and export promotion, Government of Uttar Pradesh.

As can be seen from the above Table: 2

- $\quad$ The targets set for the number of MSME units in U.P. has been achieved in all the years during the period 2004-05 to 2011-12 except slightly lower in 2005-06, 2006-07.

- The number of Employees engaged in this sector has been rising steadily from $1,21,102$ in 2004-05 to $1,86,755$ in 2011-12 which shows a jump of 65,653 and a growth of $54.21 \%$ registered during this period.

- The Capital employed has risen tremendously from Rs 284.34crore in 2004-05 to Rs 3452.93crore showing a rise of 3168.59 crore during the above period. 


\section{COMPARATIVE DATA ON NUMBER OF MSME'S IN TOP TEN STATES}

The highest number of MSME's are situated in the state of U.P. having a $14.20 \%$ share of the total MSMEs in India. With 88.67 lakh MSME's units West Bengal closely follows at second place having a $14 \%$ share. Ten States together as shown in the graph below share a total of 74.05 $\%$ out of the entire estimated number of MSMEs in the country and the rest of the States account for $25.95 \%$ of total MSME's units.

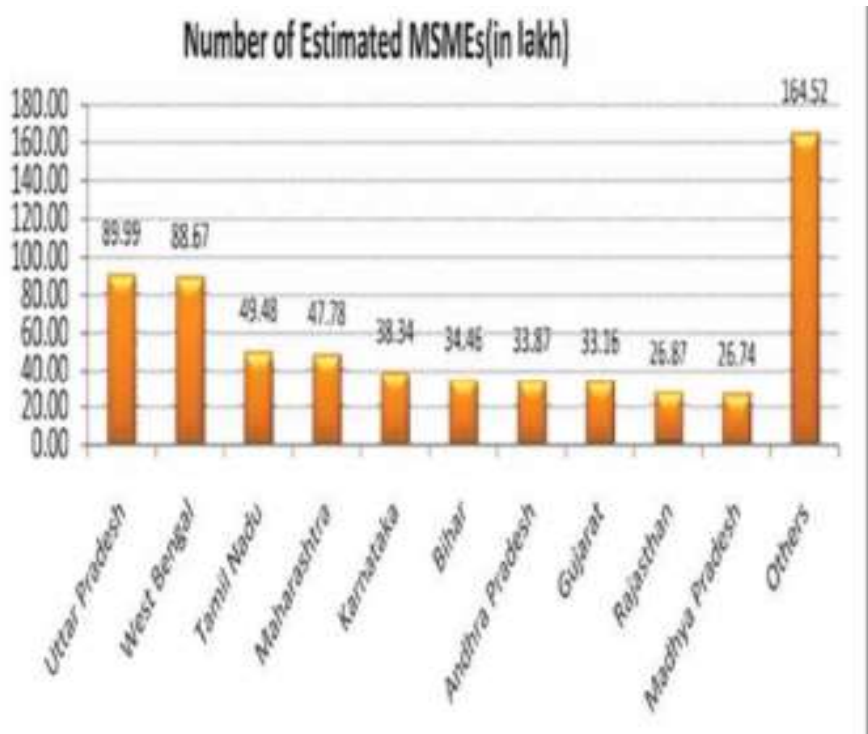

Source: MSME Report, Government of India 2018-19

NSS 73 ${ }^{\text {RD }}$ ROUND(2015-16) AND FOURTH MSME CENSUS(2006-07) ON NUMBER OF UNITS

\begin{tabular}{|c|c|c|c|c|c|}
\hline \multirow{2}{*}{$\begin{array}{l}\text { SL } \\
\mathrm{Na}\end{array}$} & \multirow{2}{*}{ State/UT } & \multicolumn{2}{|c|}{$\begin{array}{l}\text { NSS } 73^{-1} \text { round } \\
(2015-16)\end{array}$} & \multicolumn{2}{|c|}{$\begin{array}{l}\text { Fourth All India Census of } \\
\text { MSME (2006-07] }\end{array}$} \\
\hline & & $\begin{array}{l}\text { Number } \\
\text { (in takh) }\end{array}$ & Share (\%) & $\begin{array}{l}\text { Number } \\
\text { (in lalk) }\end{array}$ & Share $(\%)$ \\
\hline 1 & Uttar Pradesh & 89.99 & 14 & 44.03 & 12 \\
\hline 2 & West Bengal & 8867 & 14 & 34.64 & 10 \\
\hline 3. & Tamil Nadu & 49.48 & B & 33.13 & 9 \\
\hline 4 & Maharashtra & 47.78 & B & 30.63 & 8 \\
\hline 5 & Karnataka & 38.34 & 6 & 20.19 & 6 \\
\hline 6 & Bithar & 34.46 & 5 & 14.70 & 4 \\
\hline 7 & Andhra Pradesh"* & 3387 & 5 & 25.96 & 7 \\
\hline 8 & Gujarat & 33.16 & 5 & 21.78 & 6 \\
\hline 9 & Rajasthan & $26: 87$ & 4 & 16.64 & $\mathbf{s}$ \\
\hline 10 & Madhya Pradesh & 26.74 & 4 & 19.33 & 5 \\
\hline 11 & Total of top ten States & 469.4 & 74 & 261.04 & 72 \\
\hline 12 & Other State/UTs & 164.5 & 26 & 100.72 & 28 \\
\hline 13 & All & 633.9 & 100 & 361.76 & 100 \\
\hline
\end{tabular}

"Inducing Telangama in Fourth All Intia Census of MSME
Table: 3 Source: MSME Report Government of India, 2018-19

Table: 3 above shows the comparative status of number of Units all over the country. As can be seen as per MSME report of 2018-19, NSS $73^{\text {rd }}$ Round Uttar Pradesh is topping the chart with 89.99 lakh units having a share of $14 \%$ of the total number of MSME's in India. This share rose by $2 \%$ i.e. from $12 \%$ in $2006-07$ to $14 \%$ in $2015-16$.

\section{STATE-WISE ESTIMATION OF EMPLOYEES IN MSMES (73 ${ }^{\mathrm{RD}}$ NSS ROUND 2015-16)}

\begin{tabular}{|c|c|c|c|c|}
\hline \multirow{2}{*}{$\begin{array}{l}\text { S. } \\
\text { No. }\end{array}$} & \multirow[t]{2}{*}{$\underline{\text { States }}$} & \multicolumn{3}{|c|}{ Employment generation (in Lakh) } \\
\hline & & Female & Male & Total \\
\hline$\underline{\mathbf{1}}$ & Uttar Pradesh & 27.27 & 137.92 & 165.19 \\
\hline$\underline{2}$ & West Bengal & 43.51 & 91.95 & 135.46 \\
\hline$\overline{3}$ & Tamil Nadu & 32.27 & 64.45 & 96.72 \\
\hline$\overline{4}$ & Maharashtra & 17.97 & 72.77 & 90.74 \\
\hline$\overline{\mathbf{5}}$ & Karnataka & 19.73 & 51.11 & 70.84 \\
\hline$\overline{6}$ & Bihar & 4.79 & 48.26 & 53.05 \\
\hline$\overline{7}$ & Andhra Pradesh & 21.01 & 34.98 & 55.99 \\
\hline$\overline{8}$ & Gujarat & 13.71 & 47.44 & 61.15 \\
\hline$\overline{9}$ & Rajasthan & 8.01 & 38.31 & 46.32 \\
\hline$\underline{10}$ & Madhya Pradesh & 10.13 & 38.61 & 48.74 \\
\hline
\end{tabular}

Table: 4 Source: Annual Report (2018-19), MSME, Government of India

From the above Table: 4 it can be seen that U.P. besides leading in the number of MSME's in the country is also the leading State as far as employment generation is concerned. The workforce employed in MSME units is 165.19 lakhs as per NSS $73^{\text {rd }}$ Round, while West Bengal follows with 135,46 lakhs and Tamil Nadu with 96.72 lakhs.

\section{Conclusion}

- With around 633.9 lakh units throughout the length and breadth of the country, MSMEs contribute to around $28.90 \%$ of the GDP.

- MSME's are the second largest employment generating sector after Agriculture providing employment to around 1076.19 lakh persons in India.

- MSME ministry has set a target to up its contribution to GDP to $50 \%$ by 2025 as India strives to become a $\$ 5$ trillion economy.

- They contribute to around $49 \%$ of the overall exports from India.

- MSMEs promote inclusive growth by providing employment opportunities in rural areas especially to people belonging to weaker sections of the society. (For example: Khadi and Village industries)

- Require low per capita investment and employs a large number of women in rural areas.

- Small industries and retail businesses in tier-II and tierIII cities create opportunities for people to use banking services and products (Financial Inclusion)

- It provides opportunity for budding entrepreneurs to build creative products boosting business competition and fuels growth (promoting Innovation) 
Thus, it can be emphasized that MSME's provide jobs and employment and ultimately lead to self-dependency. The MSME's are providing uniform development of the society and removing regional imbalances in the country as well as in States. After examining the various industrial policies of Uttar Pradesh i.e. 2004, 2012 and 2017 and MSME policy 2017 it has been found that efforts of Government of U.P. have resulted in tremendous growth in the number of MSME units. Measures for investments like PPP Model (public private partnership) and implementation of schemes regarding of establishment of new MSME units in different regions of Uttar Pradesh, has resulted in modern entrepreneurs coming forward at national level and signing of various memorandums of understanding by the State Government for investments in the MSME sector. Uttar Pradesh is still one of the backward states of India but by providing good environment and logistics for MSME's it can pave the way for industrialization and growth. The Indian MSME sector is the backbone of the national economic structure and acts as a bulwark for Indian economy, providing resilience to ward off global economic shocks and adversities.

\section{REFERENCES}

[1] MSME Reports, Government of India

[2] Reports of DIC, UP.

[3] https://shodhganga.inflibnet.ac.in/bitstream/10603/438 31/6/06_chapter2.pdf

[4] David de Ferranti \& Anthony J. Ody, 2007. Beyond Microfinance: Getting Capital to Small and Medium Enterprises to Fuel Faster Development, 16 June 2013.

[5] FICCI MSME Summit, 2012. Innovation Readiness of Indian SMEs: Issues and Challenges, 15 June 2013.

[6] Industrial and Service Sector Investment Policy 2004.

[7] Uttar Pradesh Infrastructure and Industrial Investment Policy 2012

[8] Industrial Investment and Employment Promotion Policy of Uttar Pradesh 2017 